\title{
Philip Cabot
}

Philip Cabot, a member of the Business Historical Society, died on December 25, 1941, at his home in Boston. He was born in Beverly Farms on August 11, 1872, the son of James Elliot and Elizabeth Dwight Cabot. He prepared for college at the Roxbury Latin School and was graduated from Harvard College in 1894. From that time until 1920 he was in business; from 1924 until his death he was a member of the faculty of the Graduate School of Business Administration of Harvard University.

He entered business in the deep depression year of 1894 , beginning as office boy and bookkeeper in the office of William Minot, a distinguished Boston trustee and real estate manager. Cabot's special work soon came to be to collect rents. From 1904 to 1910 he managed real estate trusts.

During those years, when public utilities were swinging into strong recovery after the bankruptcies of the 1890's and the electric power industry was entering a period of rapid development, he became interested in public utilities. In 1910 he began the promotion and management of utilities, mostly electric power companies. He became the active head of a group of companies centering in the water power at Turners Falls, Massachusetts. He became interested in utilities in other places, reaching as far out as the Washington Water and Power Company, of Spokane, Washington, which company he served as trustee and also as a nember of its finance committee. From 1912 to 1918 he was resident partner in Boston of White, Weld \& Company, a New York investment banking firm. In 1918, worn out by years of intense and constant work, he was forced by ill health to retire from active participation in business.

In 1924, his health recovered, he came to the Harvard Business School as lecturer on public utility management. In 1927 he was made prof $\epsilon$ ssor of the subject, and in 1935 professor of business administration. In 1937 he became active in the development and teaching of the course on social and political aspects of business administration. For several years thereafter, he conducted the "Cabot week-ends," conferences of business executives, at the 
Business School, which considered current questions that were of inportance to business. His years at the Business School he frequently referred to as the happiest years of his life.

As a teacher and leader of younger and older men in the art of business, Professor Cabot made a unique place for himself. He was one of the few business men who have had success as a teacher. He had a forceful personality - he was a man of strong convictions and great enthusiasms. Even his language had unusual force-in his teaching he used strong words of good Anglo-Saxon origin. $\mathrm{He}$ had an unusual capacity for making students think-he relentlessly drove discussion to its logical conclusion; and he drew on a wealth of information and experience which were summed up in a definite philosophy.

His ideas were impressive to the students. Professor Cabot may be called a philosopher of business, for he looked beyond forms and institutions and techniques to the larger meaning of business as a social institution. He believed that business existed to give service, to get the job done. Hence he did not teach actual operations or techniques of utilities management as an end in themselves but as an obligation to society. He faced questions of ethics squarely-do nothing of which you would be unwilling to have a complete record printed in tomorrow morning's paper! To say that he took an ethical and a social point of view is not to say that he was a sentimentalist or collectivist; he was a realist and an intense individualist, but he believed that private enterprise could continue to exist only if it kept in mind the human needs it was serving. If business men had done their duty, he held, there would have been no place for ward politicians. He believed that a free society should be creative and wealth-producing, for only in so being could it continue to live. And it should be clynamic - any system that became static, whether a system of business or of government or society in general, was headed for revolution.

In all this there was a feeling for the human sicle of business, for the business man, the laborer, and the consumer as a person. Professor Cabot feared specialization because he thought it almost inevitably meant weakness in dealing with people. Men are emotional, and their emotional drives must be recognized.

What were the springs of Professor Cabot's character and philosophy? He came of a line of strong, one might even say stubborn, men. As a boy he learned to love and to know the mountain, forest, and sea-at eighteen he was quite able to take care of 
himself in the north woods and to cruise along the New England coast. His family was an unusual one. He and his twin, Hugh, were the youngest of seven brothers. His mother was a woman of deep interest in matters of public concern and his father was an artist and a scholar. To their home came many men and women of distinction as well as a host of young people. In his years with William Minot, Philip Cabot had a chance to work with the best lawyers and trustees of Boston as well as to learn, in his rôle as rent collector, something of life at the other end of the social and economic scale. Self-reliance, high thinking, and a sense of social responsibility were thus early implanted in the young man.

Professor Cabot said that his real education came from life, from experience and not from school or college. Be that as it may, he was free of concepts and attitudes often gained in schools, and from his experience he had gained an understanding of business that was real. He did not hesitate to be unorthodox when accepted theory conflicted with his own experience-in the 1920's students were disturbed by his view that price determined cost and not cost, price, which view he based on his public utility experience. It was this understanding of business, especially when coupled with his general social philosophy and insight and his impressive qualities as a person, that made him effective as an interpreter of business to the academic man, as a teacher of young men preparing for business, and as a leader of older men looking for help in meeting the great problems of business in recent years.

\section{Secretary's Column}

The Society has received and gratefully acknowledges the following acytrisitions:

From Mr. Henry Lee Shattuck, Boston: Pamphlet entitled Regulations of the Union Socicty of Calcutta: Instituted for the Assurance of Lizes, in April 1814; and to terminate on 30th April 1819, at Midnight.

From Federal Reserve Bank of Boston, Boston: Modern Transportation Costs (Indianapolis: Nordyke \& Marmon Co., 1923).

From First National Bank of Boston, Boston: Tables of English Sileer and Gold Coins (London: Society of Antiquaries, 1763). Also, as a loan, 